\title{
Formation of paired nouns in the Altai language
}

\section{DOI: 10.31551/2410-2725-2019-5-3-406-418}

\section{Chaychina Evgeniya Valerevna}

BNU RA «The Scientific-Research Institute of Altaistic named after S.S. Surazakov», Russian Federation, Republic of Altai, 649000, Gorno-Altaisk, 6 Sotsialisticheskaya St., research Associate in the research group of language. E-mail: ozok@mail.ru

\begin{abstract}
In all Turkic languages as in Altai widespread paired nouns, and they found none, only in spoken language and folklore, but also in various genres of fiction. Frequency of use of pairs of names in writing and speaking is linked to their semantic capacity and ability to express great stylistic, emotionally-expressive burden.

This article is devoted to the Altai language noun name pair. Paired words are inherently twofold. The components of many paired words are lexically ambiguous. They always refer to the same part of speech and even in many cases are processed the same morphological characteristics.

In Turkic languages on the subject are the works by E.I. Ubrjatova, T.M. Garipova, F.A. Ganieva, A.T. Kaidarova, S.N. Muratov, G.N. Semenova, N.M. Ondar, I.M. Tarakanova, G.A. Dyrheeva, D.Sh. Haranutova, E.A. Bardamova etc.. In the Altai linguistics paired words have so far not been the object of special study. Some of the problems are reflected in articles by N.N. Tydykova, N.R. Bajzhanova, A.V. Belyakova, E.V. Chaychina, etc. In this article we considered pairs of names and ways of their formation. Their more frequent types are revealed.

Illustrative material is selected by continuous sampling from existing dictionaries of the Altai language and also from fiction of Altai classics.

Keywords: Turkic languages; Altai language; grammar; noun; word formation; compound words; semantics; paired words.
\end{abstract}

\section{Алтай тіліндегі жұптық зат есімдердің құрылуы}

\section{Чайчина Евгения Валерьевна}

Тілдің ғылыми зерттеу тобының ғылыми қызметкері, "С.С.Суразаков атындағы алтаистика ҒЗИ" АР БҒМ, Ресей Федерациясы, Алтай Республикасы, Горно-Алтайск қ., Социалистическая көш., 6 үй. E-mail: ozok@mail.ru

Аңдатпа. Барлық түркі тілдерінде, соның ішінде, алтай тілдерінде жұптық зат есімдер кең тараған, олар тек ауызша сөйлеу мен фольклорда ғана емес, сонымен қатар, көркем әдебиеттің әртүрлі жанрларында жиі кездеседі. Жазу мен ауызша сөйлеуде жұптық зат есімдердің қолданылуы, олардың мағыналық көлемі мен стилистік, эмоционалды-экспрессивті жағдайды айқындауға байланысты болады.

Мақала алтай тілінің жұптық зат есімдерін зерттеуге бағытталған. Жұптық сөздерге екі құрылымдық тән. Көптеген жұптық сөздердің компоненттері лексикалық жағынан әртүрлі мағыналы. Олар сөйлеудің бір бөлігіне әрдайым қарайды және көптеген жағдайларда да бірдей морфологиялық көрсеткіштермен ресімделеді.

Түркі тіліндегі бұл мәселе бойынша Е.И. Убрятова, Т.М. Гарипов, Ф.А. Ганиев, А.Т Кайдаров, С.Н. Муратов, Г.Н. Семенова, Н.М. Ондар, И.М. Тараканова, Г.А. Дырхеева, Д.Ш. Харанутова, Е.А. Бардамова және тағы басқалардың еңбектері бар. Бүгінгі күнге дейін алтай тілтануында жұптық сөздер арнайы зерттеу нысаны болған емес. Кейбір жеке мәселелер Н.Н. Тыдыкова, Н.Р. Байжанова, А.В. Белякова, Е.В. Чайчина және тағы басқалардың мақалаларында көрініс тапқан. Бұл мақалада жұмысында алтай тіліндегі жұптық зат есімдерінің қалыптасу ерекшеліктері талданған. Олардың жиіліктік түрлері анықталады. Иллюстрациялық материал Алтай тілінің қолданыстағы сөздіктерінен және Алтай классиктерінің көркем әдебиетінен жаппай іріктеу жолымен алынған.

Түйін сөздер: түркі тілдері; алтай тілі; грамматика; зат есім; сөз құрастыру; семантика; жұптық сөздер. 


\title{
Образование парных имен существительных в алтайском языке
}

\section{Чайчина Евгения Валерьевна}

БНУ РА «НИИ алтаистики имени. С.С. Суразакова», Российская Федерация, Республика Алтай, 649000, г. Горно-Алтайск, ул. Социалистическая, д. 6, научный сотрудник научноисследовательской группы языка. E-mail: ozok@mail.ru

\begin{abstract}
Аннотация: Во всех тюркских языках, как и в алтайском широко распространены парные имена существительные, причем они встречаются ни, только в устной речи и фольклоре, но и в различных жанрах художественной литературы. Употребительность парных имен в письменной и устной речи связана с их смысловой емкостью и способностью выражать большую стилистическую, эмоционально-экспрессивную нагрузку.

Настоящая статья посвящена парным именам существительным алтайского языка. Парным словам присуща двусоставность. Составные компоненты многих парных слов лексически разнозначные. Они всегда относятся к одной и той же части речи и даже во многих случаях оформляются одинаковыми морфологическими показателями.

В тюркских языках по данному вопросу имеются работы Е.И. Убрятовой, Т.М. Гарипова, Ф.А. Ганиева, А.Т Кайдарова, С.Н. Муратова, Г.Н. Семеновой, Н.М. Ондар, И.М. Таракановой, Г.А. Дырхеевой. Д.Ш. Харанутовой, Е.А. Бардамовой и др. В алтайском языкознании парные слова до настоящего времени не были объектом специального исследования. Некоторые отдельные проблемы отражены в статьях Н.Н. Тыдыковой, Н.Р. Байжановой, А.В. Беляковой, Е.В. Чайчиной и др. В данной статье нами рассматриваются парные имена и способы их образования. Выявляются более частотные их типы.

Иллюстративный материал отобран путем сплошной выборки из существующих словарей алтайского языка и также из художественной литературы алтайских классиков.

Ключевые слова: тюркские языки; алтайский язык; грамматика; имя существительное; словообразование; словосложение; семантика; парные слова.
\end{abstract}

\section{УДК/UDC 811.512.151}

\section{Образование парных имен существительных в алтайском языке}

\section{E.В. Чайчина}

Введение. В безаффиксальном образовании имен существительных в алтайском языке выделяются следующие способы: 1) словосложение; 2) лексикализация словосочетаний; 3) переход словосочетания в сложное слово при его одновременной аффиксации, 4) конверсия; 5) лексико-семантический (разложение лексемы на омонимы); 6) аббревиация.

Из выделенных способов не все обладают одинаковой продуктивностью. Самыми продуктивными способами словообразования являются способы словосложения и лексикализация словосочетаний. Менее продуктивными переход словосочетания в сложное слово и разложение лексемы на омонимы.

Словосложение - способ словообразования, который заключается в соединении двух или редко нескольких простых основ в одно сложное слово. Выделяются два способа словосложения: словосложение с сочинительным отношением компонентов (образование парных слов); словосложение с подчинительным отношением компонентов (сложение с атрибутивным отношением компонентов). Словосложение с сочинительным отношением компонентов в современном алтайском языке характеризуется равноправным включением исходных компонентов в образованную сложную основу. Продуктом этого способа является парное слово, которое характеризуется тем, что обе исходные основы равноправно включены в образованную сложную основу, исходные основы находятся в общем семантическом поле. Сложная основа в одних случаях имеет более отвлеченное значение, а в других - 
большую собирательность, иногда сумму исходных значений (Наделяев, 1988: 35).

Предметом исследования являются парные имена существительные алтайского языка. Парным словам характерна двусоставность. Составные компоненты многих парных слов лексически разнозначные. Они всегда относятся к одной и той же части речи и даже во многих случаях оформляются одинаковыми морфологическими показателями.

Материалы и методы. Материал исследования анализируется путем сплошной выборки из словарей: «Ойротско-русский» (Ойротско-русский словарь, 1947), «Алтайско-русский» под редакцией Н.И. Когунбаевой (Когунбаева, 1991), «Морфемный словарь алтайского языка» (Морфемный словарь алтайского языка, 2005), «Алтайско-русский словарь» (Алтайскорусский словарь, 2018), а также из алтайского героического эпоса и из произведений художественной литературы алтайских классиков. При изучении темы применялся метод семантического анализа образования парных имен.

Обсуждение. В тюркских языках парные слова являются объектом пристального внимания и специального изучения. Им посвящены работы Е.И. Убрятовой (Убрятова, 1948), Т.М. Гарипова (Гарипов, 1959), Ф.А. Ганиева (Ганиев, 1982), А.Т. Кайдарова (Кайдаров, 1958), Муратова (Муратов, 1961), Г.Н. Семеновой (Семенова, 2005), Н.М. Ондар (Ондар, 2004), И.М. Таракановой (Тараканова, 2008), Г.А. Дырхеевой, Д.Ш. Харанутовой, Е.А. Бардамовой (Дырхеева и др., 2014) и т.д. В указанных работах по тюркским языкам с достаточной глубинной раскрыты лексико-семантические особенности парных слов.

Парные существительные, по определению А.Н. Кононова, - это сложные имена существительные, которые образуются путем сложения пары слов, и в зависимости от лексического значения и формы компонентов, приобретают семантику собирательности, обобщения, экспрессивности или стилистической модификации наличных в компонентах лексических значений (Кононов, 1956: 135).

В «Грамматике башкирского языка» Н.К. Дмитриев выделяет 4 типа парных слов. К первому типу он относит слова, которые образованы: dys-uш (друг, приятель) - 'товарищ, советник' 2 тип: may-maш (камни и горы) - 'гористокаменистая местность'. 3 тип: ыласын-һыласын (соколы и тому подобные) порусски было бы «сокол-мокол» һыласын - слово, отдельно не имеющее никакого значения. 4 тип: аzай-эне 'братья' (Дмитриев, 1948: 74).

Структурные особенности парных слов в якутском языке рассмотрела Е.И. Убрятова в статье «Парные слова в якутском языке». Она выделила два способа образования парных слов: согласования и примыкание. Термины согласование и примыкание имеют в данном случае иное значение, чем принято в русистике: «Согласование как способ связи слов в предложении имеет несколько другой характер и применение, чем, например, в русском языке.... В некоторых тюркских языках, в которых существует стремление особо подчеркивать внутреннюю связь между однородными членами предложения, согласование используется для выражения синтаксических отношений между однородными членами. В этом случае согласование имеет сочинительный характер, так как оно связывает собой два равноправных члена предложения...» (Убрятова, 1948: 298). Основной закономерностью образования парных слов как отмечает А.Т. Кайдаров, является то, что «компоненты парных слов в обязательном порядке относятся к одной и той же части речи» (Кайдаров, 1958: 13). По лексическим особенностям, т.е. по 
наличию или отсутствию самостоятельных значений у компонентов Ф.А. Ганиев делит парные слова, на следующие типы:

1. Оба компонента парного слова в языке существуют самостоятельно и имеют реальное значение.

2. Первый компонент парных слов отдельно существует в современном языке, и имеют реальное значение, а второй наблюдается в диалектах, родственных языках или имел место в древнем состоянии языка. Таким образом, второй компонент парного слова является этимологически затемненным.

3. Первый компонент парного слова самостоятельно существует в языке и имеет лексическое значение, а второй же только является его фонетически измененным вариантом без реального значения, отзвуком, его асемантическим аналогом (Ганиев, 1982: 59).

Первое упоминание о парных словах в алтайском языке встречается в «Грамматике алтайского языка составленной членами Алтайской миссии»: «В алтайском языке нередко употребляются, для выразительности и части для украшения речи, удвоения слов: ел јон или јон улус 'народ'. Или второе слово искусственно составляется созвучно первому: ыныр чыныр 'скрип'...» (Грамматика алтайского языка, 2005: 30). В «Грамматике ойротского языка» указано, что «соединение двух слов может иметь значение отличное как от значений этих слов, каждого в отдельности, так и от значения суммы этих слов, например: ада-эне 'родители' (отец и мать), айак-казан 'утварь, посуда (чашка и котел)' (Грамматика ойротского языка, 1940: 42). В «Грамматике современного алтайского языка. Морфология» (Грамматика алтайского языка, 2017: 71-72) выделяются лексико-семантические особенности парных слов и лексико-семантические взаимоотношения компонентов парных слов.

Современные подходы по проблеме отражены в статьях Н.Н. Тыдыковой «Лингвистическая характеристика женских имен в алтайском героическом эпосе» (Тыдыкова, 2003: 71-79), Н.Р. Байжановой «Образование парных слов в алтайском языке» (Байжанова, 2002: 101-103), А.В. Беляковой «О парных словах образованных из синонимов» (Белякова, 2002: 52-57), И.Н. Муйтуевой «Парные слова в алтайском языке» (Муйтуева, 2012: 152-154), Е.В. Чайчиной «Безаффиксальное словообразование имен существительных» (Грамматика алтайского языка, 2017: 69-75) и т.д.

Результаты. Как отмечают авторы «Грамматики современного алтайского языка», «...парные слова по семантике имеют свои отличительные особенности, так, общее значение парного слова может быть: а) шире, чем значения составляющих парное слово компонентов, например: калганчы сӧс 'вердикт' (калганчы 'последний', сӧс 'слово'); б) приблизительно равным, но более обобщенным: јол-јорык 'путешествие' (от јол 'путь, дорога', јорык 'путь, путешествие, поездка').

В некоторых парных именах существительных существует твердый порядок расположения компонентов. Например: ан-куш 'звери' (от ан 'зверь', куш 'птица'); агаш-таш 'деревья и камни' (от агаш 'дерево', таш 'камень'); ичкарын 'внутренности' (от ич 'живот, брюхо', карын 'живот, желудок'); в этих парных словах компоненты располагаются только в таком порядке, а не

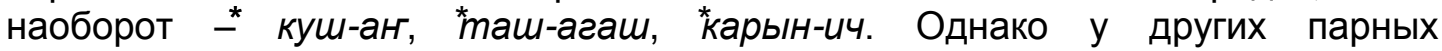
существительных порядок расположения компонентов допускает вариантность: айак-казан - казан-айак 'посуда', эрмек-куучын - куучын-эрмек ‘беседа’ и т. д. (Грамматика алтайского языка, 2017: 69). 
Компоненты парных слов могут характеризоваться разнообразными лексико-семантическими особенностями. Как ранее упоминалось, в татарском языке Ф.А. Ганиев выделяет лексико-семантические особенности компонентов парных слов следующим образом:

1. Оба компонента парного слова в языке существуют самостоятельно и имеют реальное значение.

2. Первый компонент парных слов отдельно существует в современном языке, и имеют реальное значение, а второй наблюдается в диалектах, родственных языках или имел место в древнем состоянии языка. Таким образом, второй компонент парного слова является этимологически затемненным.

3. Первый компонент парного слова самостоятельно существует в языке и имеет лексическое значение, а второй же только является его фонетически измененным вариантом без реального значения, отзвуком, его асемантическим аналогом (Ганиев, 1982: 218).

Придерживаясь точки зрения Ф.А. Ганиева, лексико-семантические особенности компонентов парных имен существительных алтайского языка выделяем на следующие типы:

1) оба компонента парного слова в языке существуют самостоятельно и имеют реальное значение, например: мал-јон 'скот-народ' (от мал 'скот', јон 'народ' ), айыл-јурт 'дом' (от айыл '1. дом (семья); 2. юрта', јурт 'место жительства, селение'), эрмек-табыш 'новость' (от эрмек '1. беседа, разговор; 2. предложение', табыш '1. звук; 2. слух, известие, новость'), эрмек-сӧс 'известие, новость' (от эрмек 'беседа, разговор', сӧс 'слово'), јуу-чак 'война' (от јуу 'война', чак 'время, пора)', ӧкпӧ-јӱрек 'внутренности' (от ӧкпӧ 'легкие', јӱрек 'сердце'), айак-калбак 'посуда' (от айак 'чашка, тарелка' калбак 'ложка'), ойынкаткы 'веселье, смех, шутки с забавами и играми' (от ойын 'игра, забава' каткы 'смех'), ойын-кокыр 'смех, шутка, юмор' (от ойын 'игра, забава' кокыр 'шутка, шутки в разговоре, веселый разговор') и т.д.

Примеры: Ак-Бӧкӧ јетен јылга, Малын кӧрбӧйтир. Эмди Ак-Борозын минип алып, Малын-јонын кӧрӧргӧ јортып ийди (АБ, 37) - 'Семьдесят лет, оказывается, Ак-Беке, Не осматривал своего скота. И вот сел он на свою лошадь Ак-Боро, Он поехал посмотреть на свой скот, на свой народ'; КатанМерген Кара-Калтарын туура тартты, Айлын-јуртын кӧстӧп элес эдип, Јӱрип ийди (АБ, 38) - 'Катан-Мерген повернул (своего коня) Кара-Калтара, И быстро по направлению дома. Помчался; «Бойымнын јуртым деп, Келген јери, адазынын јурты эмтир. Эрмек-табыш угар» - деп, Адазынын јуртына mӱшти (АБ, 38) - '«Я подумал, что приехал в свою страну, А это оказывается, стойбище своего отца. Надо поговорить и послушать (новости)» решил он'.

2) ко второму типу относятся парные имена, где первый компонент парных слов отдельно существует в современном языке, и имеют реальное значение, а второй наблюдается в диалектах, родственных языках или имел место в древнем состоянии языка. Например, солун-собур 'новость, весть' (от солун 'весть'). Второй компонент данного слова самостоятельно в языке не существует. В настоящее время второй компонент парного слова в лексике носителей языка не фриксируется. Данное слово можно встретить в художественной литературе: Кузлеков печкеге оттон кӥркӱреде салып, кӧӧшти азып, какайдын эдин тӱлип ийген (AА, ТJ, 28) - 'Кузлеков, разведя в печке трескучий (букв. так, чтобы трещал) огонь, поставив чугунок, сварил мясо кабана'. 
Примеры: Јети кезер мойношпой, Саадактарын јӱктендилер, Азык-тӱлӱк артынып, Андап эмди атандылар (ЭР, 45) - 'Семь силачей, не возражая, Луки свои на плечо положили. (На лошадей) продукты навьючив, На охоту отправились'; Тузагаш Тӧдӧкӧнӧн солун-собурды угуп, айылга кирди (ИШ К, 163) - 'Узнав новости у Тоодоко, Тузагаш зашел в юрту'; Маадай солунсобурын тӧкпӧй-чачпай кууучындап берди (ТШЫЭИ, 51) - 'Не проронив ни одного слова Маадай, рассказал свои новости'.

3) третий тип, где первый компонент парного слова самостоятельно существует в языке и имеет лексическое значение, а второй же только является его фонетически измененным вариантом без реального значения, отзвуком, его асемантическим аналогом: јылкы-мылкы 'неезженая лошадь; табун коней' (от јылкы 'неезженая лошадь'), кир-тор 'грязь' (от кир 'грязь'), ишmош 'работа' (от иш 'работа'), эски-саскы 'старьё' (от эски 'старый, изношенный'), уй-сай 'корова' (от уй 'корова и тому подобное'), торбок-сарбак 'бык и тому подобное' (от торбок 'бык'), баскын-тоскын 'бродяга' (от баскын 'бродяга'), картошко-сартошко 'картофрель' (от картошко 'картошка'), кудакууй 'сватовство' (от куда 'сватовство; сватанье'), куучын-кубуй 'разговор, беседа' (от куучын 'разговор') т.д.

Примеры: Куда-кууй тыный берди, кулун эдин амзай берди (АБ) 'Сватовство вошло в раж, мясом жеребенка стали угощаться'; Канза азыш, куучын-кубуй туку качан кӧндӱгип калган (ЭТ, К, 34) - 'Курение трубок, беседа давным-давно продолжаются'.

В данном типе можно выделить следующие фонетические изменения:

1. Наблюдается чередование двух рядов словоформ, а внутри них замена мягкорядных гласных независимо от лабиализованности на гласные твердого ряда $а$.

cÿm-cam 'молоко' (от сйm 'молоко), кӧчӧ-кача 'суп с перловкой и т.п.' (от кӧчӧ 'перловка'): Иитенип турган улуска кӧчӧ-качана артык курсак јок болбой (АЛ, 3) - 'Наверное, рабочим лучше перловки нет еды'.

2. Второй элемент строится путем замены начального согласного первой основы на фоонему $M, c, m$.

Переход глухого согласного в звонкий согласный $c>M$ :

- сўӱш-мӱўш 'любовь' (от сйӱш 'любовь'): Бис тен сйӱнип отурыс: јуртка jурт, кижиге кижи кожулар деп. Бис эмди јаан улус кайдан анда сӱӱш-мйӱш (ТШЫЭИ, 246) - 'Мы сидим, радуясь: семье прибавиться еще семья, человеку человек. Мы теперь взрослые, какая там любовь (бук. любовь-морковь)'.

- картошко-мартошко 'картофель' (от картошко 'картошка'): Картошкосартошко сурап алар керек (АЛ, 89) - 'Надо бы попросить картошку'.

- јылкы-мылкы 'табун необъезженных лошадей' (от јылкы 'неезженая лошадь'): Јылкы-мылкы кайда барар ол. Эзенде онон кӧп болор онын учун сӧйор ло - 'Куда денутся лошади. На следующий год их еще много будет, поэтому колите'.

$-\kappa>C$ :

кӧс-сас 'глаза' (от кӧс 'глаза'), кан-сан 'кровь' (от кан 'кровь'): Кӧс-сас та уйан кӧрӱп баштады (ААУБТ, 432) - 'Глаза то стали плохо видеть'; кижи-сажы 'бук. всякие люди' (кижи 'человек'): Кижи-сажыла куучындашпай, јылдыра бас. Аймактан-эштен келген улуска кӧрӱнбей бар (ЛКА, 73) - 'Иди быстрей, не разговаривая по пути со всякими людьми. И не показывайся людям, которые приехали с района'; Канын-санын јунуп алды, Тонын-санын эптеп алды (АБ, 67) 'Надел поудобнее свою одежду, (Эрзамыр) смыл с себя кровь и грязь'.

$$
-m>c \text { : }
$$


торбок-сарбак 'бык' (от торбок 'бык'): Торбок-сарбакла кӱрешкенче, барып бӧкӧ уулдарла кӱреш деп, Кӧрӱш бай Ирбизекке јакарган аайлу айтты (ИШ КJ, 295) - Чем бороться с быками, иди бороться с сильными парнями, будто приказывая, сказал Ирбизеку, бай Керуш'.

$\kappa>m:$

кир-тор 'грязь' (от кир 'грязь'): Ай Буркан кирден-тордон арутазын, тӱбектен, јеткерден аргадап јӱрзин (АЛ, 53) - 'Пусть Ай Буркан очистит от грязи, спасет от горя и несчастья'.

3. При образовании парных слов второй компонент приобретает дополнительный звук:

иш-тош 'работа' (от иш 'работа'): Јайлуга кӧчӱп келгенде иш-тош кӧптӧй берди (ИШ КЈ, 214) - 'С переселением на летник работы стало много';

эски-саскы 'старьё' (эски 'старый, изношенный'): Басек айылдын эжигин ачып кӧрзӧн эски-саскыдан ӧскӧ не де кӧрӱнбеди (АЛ, 93) - 'Когда Басек открыл дверь дома, кроме старья ничего не увидел'.

уй-сай 'корова' (уй 'корова'): Уй-сай ла кабырып бош карыдым (АА УБТ, 65) - 'Пася, коров и состарился'.

Следует отметить, что во многих языках значение множественности часто переходит в значение отрицательной оценки объектов - значение пренебрежительности (Мельчук, 1998: 196). Этот переход семантически естественен: качественная ущербность объекта является важной предпосылкой для его «деиндивидуализации»; совокупность плохого легко образует собой качественное единство и не вызывает желания искать отличия между отдельными его элементами (Мельчук, 1998: 280). Значение пренебрежительности и уничижительности довольно естественно развивается из значения типа 'всякий', 'разный'. Оно наиболее экспрессивно по отношение к одушевленным объектам (Плунгян, 2000: 112).

баскын-тоскын 'бродяга': Баскын-тоскын дешпегер, Барагашта айлым бар (AJ, 179) - 'Не говорите, что я бродяга, в Барагаше есть мой дом';

талтак-мылтак 'раскоряка': Талтак-мылтак ла болзо, санаа салбайтан ба? (АЛ, 45) - ‘Если раскоряка, то в него невозможно влюбиться?';

Алтай-мултай 'алтаец': Тере тонду алтай-мылтай да дешсе, Туулу Алтайда чыккам - 'И пускай говорят, что я алтаец в шубе овчиной, родился я в Горном Алтае';

аксак-йксек 'старик, бук: хромой' (аксак 'хромой'): Бу отурган аксак-йксек онду неме де айтпайт (ЭТ К, 141) - 'Ничего нормального не говорит, этот сидящий старик';

Јуртта немени эдер-тудар чыдалду, билгирлӱ кижи де јок ине. Аксакӱксектер агашла узанып билбезим дежер (ЭТ К, 141) - 'Ведь в деревне и человека та нету, который делал что-то (бук. мастер по резьбу дерева) с умением и терпением. Старики говорят, что не умеют мастерить из дерева'.

Большинство из этих существительных являются авторскими образованиями и встречаются как в художественной литературе, так и разговорной речи.

В ходе работы из фрактического материала выявлено, что парные имена существительные алтайского языка с точки зрения лексико-семантического соотношения компонентов выделяются на три типа: синонимические, антонимичные и ассоциативные.

1. Характерной особенностью первого типа является наличие в них обобщающего собирательного значения, вытекающего из соединения названия конкретных предметов или явлений, например: бала-барка 'дети' (от 
бала 'дитя, ребенок' барка 'внук, внучка'), ийде-кӱч 'сила' (от ийде 'мощь', кӱч 'сила'), калык-јон 'народ' (от калык 'народ, население' јон 'народ'), оору-јобол 'болезнь' (от оору 'болезнь' јобол '1. болезнь, изнеможение; 2. хлопоты, затрата энергии, времени на хлопоты'), меке- тӧгӱн 'ложь' (от меке 'хитрость, обман', тӧгӱн 'обман'); ый-сыгыт 'плач' (от ый 'плач', сыгыт 'причитание'), албан-шыра 'бедствие' (от албан 'насилие, принуждение', шыра 'мука, мучение', эрмек-куучын 'речь, разговоры' (от эрмек 'беседа, разговор', куучын '1. повесть, рассказ; 2. разговор, беседа'), кӧрӱш-таныш 'знакомые' (от кӧрӱш 'знакомый', таныш 'знакомый'), чырай-бӱдӱш 'лицо' (от чырай 'лицо, черты лица', бӱдӱш 'внешность, внешний вид') и т.д.

Данный тип парных слов является наиболее многочисленным. Они охватывают почти все основные части речи: существительные, прилагательные, наречия, глагольные формы. Употребление синонимических парных имен существительных в художественной литературе, в речи носителя языка передает полное смысловое значение слова.

Примеры: Ый-сыटыт, уйлардын мӧӧрӧжи ле койлордын мааражы кижинин кулагын тундурып, эки јанындагы тууларга јаныланып, ыраакка угулып турды (ИШ, КЈ, 142) - 'Слышались вдалеке плач, мычанье коров и блеяние овец, оглушая людей и отдаваясь в горах с двух сторон'; Албаншырада јаткан албатынын јёрӱми баштап бистин кӧскӧ илинбей јат 'Сначала не бросается в глаза жизнь народа, который живет в бедствии'; Кӧрӱш-таныш кыстарым да толтыра (СС, Э, 187) 'Знакомых девушек то полно; Чырай-бӱдӱжер кандый да кеберкек болзо, кӧксигер ойлу болзо, слкрди јараш деп кем де айтпас - 'Каким бы миловидным ни было ваше лицо, какой бы умной вы ни были, никто не скажет, что вы красивы'.

2. Ко второму типу парных слов относятся следующие парные имена: адаэне 'родители' (от ада 'отец' эне 'мать, мама'), ан-куш 'звери' (от ан 'зверь' куш 'птица'), тон-ӧдӱк 'одежда' (от тон 'пальто', ӧдӱк 'обувь, сапоги'), јер-суу 'земля-вода' (от јер 'земля', суу 'вода'); куда-кудагай 'сваты' (от куда 'сват', кудагай '1. сестра жены старшего брата; 2. сваха; 3. сватья'), агаш-таш 'лес' (от агаш 'дерево', таш 'камень'). Из фрактического материала видно, что данный тип не так многочислен. Результатом подобного сочетания обычно являются слова с абстракты, отвлеченным значением.

Примеры: Ай-кӱн ӱрелер деп, радиоло айтты 'По радио передали, что погода испортится'; Јоткон тон-ӧдӱгин суурып, илип, тӧр јаар ӧтmи (ТШ, AJ, 5) 'Сняв и повесив одежду, Дьоткон прошел на почётное место в доме'; ўйи ачынала эне-адазына јӱре берген (ЭП, А, 30) ЖЖена обидевшись ушла к родителям'; Ада-энези јӧп бербеген (АА, ӦЧК, 199) 'Родители согласия не дали', Онын эне-адазы мында болтыр (AЕ, КJ, 22) 'Его родители, оказывается, были здесь'; Эбиреде агаш-таш карудан кару! (AE, КЈ, 4) 'Лес вокруг милее всего!'.

3. Особенностью этого третьего типа является то, что они относятся к одному кругу понятий и представлений. Семантические компоненты ассоциативных парных слов соотносятся друг с другом как видовые понятия, объединяемые в более общие родовые понятия. При этом выражают значение собирательности и обобщенности: аш-курсак 'еда, пища' (от аш '1. еда, пища; 2. хлеб; зерно, хлебные злаки' курсак 'пища, питание'), бичик-билик 'грамота' (от бичик 'книга', билик 'знание', чӥм-јан 'традиция, обычай' (от чӱм '1. наряд; 2. мода', јан '1. власть; 2. вера; 3. обычай, закон'), курт-коныс 'насекомое' (от курт 'червь' коныс '1. жук; 2. насекомое'), алама-шикир 'сладости, пряности' (от алама 'яблоко' шикир 'сахар', јуу-јепсел 'вооружение, оружие' (от јуу '1. 
война; 2. сражение, бой, битва' јепсел '1. утварь, инвентарь, набор инструментов, орудия производства; 2. снаряжения, доспехи'), мылтык-јепсел 'оружие, вооружение' (от мылтык 'ружье', јепсел '1. утварь, инвентарь, набор инструментов, орудия производства; 2. снаряжения, доспехи'), ӧкпӧ-јӱрек 'внутренности' (от ӧкпӧ ‘легкие', јӱрек 'сердце') и т.д.

Примеры: Ак-Сары ат Кара-Кӱренди, Арка-мойнын ӱзе тиштеп, ӧкпӧјӱрегин јаара тееп, јеелип јӱрди (ЭС, 43) - 'Конь Ак-Сары перегрыз, Шею и спину Кара-Кюрену, Перебив ногами его внутренности, Рысью бегает (в поле); Эчей-Буудай энези, Алтын столына аш-курсагын салып ийди. Алтын тажуур арагызын тургузын ийди, Эр-Самырын, уулын кӱндӱледи (ЭС, 74) - '(Мать ЭрСамыра) Эчей-Буудай, Расставила на золотом столе разные яства. Поставили золотой тажуур с аракой, И стала угощать своего сына Эр-Самыра'; Бир уйа чымалы бир гектар јердин агаштарын ла ӧзӥмдерин јеткерлӱ куртконустын аргадап алат (ИС,ТУКА, 87) 'Муравьи из одного муравейника могут спасти деревья и растения с одного гектара земли от опасных насекомых'.

Как отмечают Г.Д. Дырхеева, Д.Ш. Харанутова, Е.А. Бардамова, «...в основе образования парных слов лежит семантическая закономерность, слова объединяются в одно целое на основе каких-либо семантических отношений: синонимических, антонимических и ассоциативных, и представляют собой паратактическое сочетание двух равнозначных компонентов без специального морфологического оформления, которое предполагает простое соположение частей единого целого - нового слова» (Дырхеева и др., 2014: 149-150).

Заключение. Таким образом, предварительный анализ иллюстративного материала показывает, что парные слова алтайского языка встречаются почти во всех произведениях художественной литературы и в фольклоре. Если рассматривать компоненты парных имен существительных по лексикосемантическими особенностям, то по частоте употреблений можно выделить следующий тип парных имен, где оба компонента парного слова в языке существуют самостоятельно и имеют реальное значение. К менее частотным относятся, где первый компонент парных слов отдельно существует в современном языке, и имеют реальное значение, а второй наблюдается в диалектах, родственных языках или имел место в древнем состоянии языка.

Также следует отметить, что большинство из парных имен существительных являются авторскими образованиями и встречаются как в художественной литературе, так и разговорной речи. Здесь также необходимо обратить внимание на одно очень важное свойство парных слов. Это касается отношения самого носителя языка, который обладает потенциальной возможностью образовать парные слова, которые молниеносно придумываются им для выражения какого-либо понятия и тут же могут быть забыты им самим же. Во всяком случае, парные слова представляют легкодоступную форму словообразования для носителей языка. Безусловно, не всякое образование подобного характера можно считать уже парными словами, ибо для этого они должны обладать определенными свойствами лексической единицы.

Широкое употребление в лексике алтайского языка разнообразных структурных типов парных существительных для выражения определенных лексико-семантических значений подтверждает мысль о том, что аналитический способ образования парных слов является продуктивным способом словообразования в современном алтайском языке. 


\section{Әдебиеттер тізімі / Список литературы}

1. Алтайско-русский словарь, 2018 - Алтайско-русский словарь. - Горно-Алтайск, 2018. - 936 с. (на русс., алт. языках)

2. Байжанова, 2002 - Байжанова Н.Р. Образование парных слов в алтайском языке // Третья зимняя типологическая школа: Международная школа по лингвистической типологии и антропологии. Московская область, 29 января - 6 фревраля 2002. Материалы лекций и семинаров. М.: РГГУ, 2002. - С. 101-103.

3. Белякова, 2006 - Белякова А.В. О парных словах, образованных из синонимов // Филологические исследования (к 100-летию Т. М. Тощаковой). Горно-Алтайск, 2006. - С. 52-57. 4. Ганиев, 1982 - Ганиев Ф.А. Образование сложных слов в татарском языке. М.: Наука. 1982. $-150 \mathrm{c}$.

5. Гарипов, 1959 - Гарипов Т.М. Башкирское именное словообразование. Уфа: БФ АН ССР, 1959. - $221 \mathrm{c}$.

6. Грамматика, 2005 - Грамматика алтайского языка. Репринтное воспроизведение издания «Грамматика алтайского языка», (Казань, 1869). - Горно-Алтайск: издательство «Ак Чечек», 2005.

7. Грамматика, 2017 - Грамматика современного алтайского языка. Морфология. - ГорноАлтайск, 2017. - 576 с.

8. Дмитриев, 1948 - Дмитриев Н.К. Грамматика башкирского языка. - М.; Л., 1948. - 607 с.

9. Дыренкова, 1940 - Дыренкова Н.П. Грамматика ойротского языка - М.; Л., 1940. - 304 с.

10. Дырхеева, Харанутова, Бардамова, 2014 - Дырхеева Г.А., Харанутова Д.Ш., Бардамова Е.А. Парные слова и парное словообразование в бурятском языке. - Улан-Удэ, 2014. - 208 с.

11. Кайдаров, 1958 - Кайдаров А. Парные слова в современном уйгурском языке. - Алма-Ата, 1958. - 168 с.

12. Когунбаева, 1991 - Когунбаева Н.И. Алтайско-русский словарь. Горно-Алтайск, 1991.

13. Кононов, 1960 - Кононов А.Н. Грамматика современного узбекского литературного языка. М.; Л. 1960. - 446 с.

14. Мельчук, 1998 - Мельчук И.А. Курс общей морфологии. ІІ. М.: Вена, 1998.

15. Морфемный словарь алтайского языка, 2005 Морфемный словарь алтайского языка. ГорноАлтайск, 2005. (на русс., алт. языках).

16. Муйтуева, 2012 - Муйтуева И.Н. Парные слова в алтайском языке // Языки и литература народов Горного Алтая: междунар. ежегодник. - Горно-Алтайск: РИО ГАГУ, 2012. - С.152-154.

17. Муратов, 1961 - Муратов С.Н. Устойчивые словосочетания в тюркских языках. М.: Восточная литература, 1961. - 131 с.

18. Наделяев, 1988 - Наделяев В.М. Современный монгольский язык. Морфология. Новосибирск: Наука, 1988. - 113 с.

19. Ойротско-русский словарь, 1947 - Ойротско-русский словарь. М.: ОГИЗ. 1947. (на русс., алт. языках)

20. Ондар, 2004 - Ондар Н.М. Соматические парные слова в тувинском языке // Актуальные проблемы сохранения и развития языков, культур и истории народов Саяно-Алтая: Материалы междунар. науч. конф., посвященной 280-летию открытия древнетюркской письменности. 20-23 сентября 2001 г. Абакан, 2001. - С.108-112.

21. Плунгян, 2000 - Плунгян В.А. Общая морфология. Введение в проблематику. М, 2000.

22. Семенова, 2005 - Семенова Г.Н. Композитообразование в чувашском языке и его национальная специфика. М, 2005. - 318 с.

23. Тараканова, 2008 - Тараканова И.М. Словообразование имен существительных в хакасском языке (в сопоставительном аспекте). - Абакан, 2008. - 174 с.

24. Тыдыкова, 2003 - Тыдыкова Н. Н. Лингвистическая характеристика личных имён в героическом эпосе // Исследования по алтайскому языку. Горно-Алтайск, 2003. - С.71-79.

25. Убрятова, 1948 - Убрятова Е. И. Парные слова в якутском языке // Язык и мышление. - М.; Л.: Изд-во АН СССР, 1948. № II. - С.297-328.

26. Чайчина, 2015 - Чайчина Е.В. Безаффриксальное словообразование имен существительных // Грамматика современного алтайского языка. Морфология. Горно-Алтайск, 2017. - С.69-75.

\section{Текстовые источники и информанты}

АА, ӦЧК - А. Адаров. Ӧлӱмнин чанкыр кужы. - Горно-Алтайск: книжное издательство «ЮчСюмер», 1993.

АА, ТJ - А. Адаров. Тӱндеги јылдыстар. - Горно-Алтайск: Горно-Алтайское отделение Алтайского книжного издательства, 1961.

АА, УБТ - А. Адаров. Уча берген турналар. - Горно-Алтайск: Горно-Алтайское отделение Алтайского книжного издательства, 1980. 
АБ - Алтай баатырлар. I-XII т.т. - Горно-Алтайск: Горно-Алтайское отделение Алтайского книжного издательства, 1959-1995.

AJ - Алтай јан / Сост.: В.А. Муйтуева, М.П. Чочкина. - Горно-Алтайск: Горно-Алтайская типография, 1996.

$\mathrm{AE}, \mathrm{KJ}$ - А. Ередеев. Куулгазынду јай. - Горно-Алтайск: Горно-Алтайское отделение Алтайского книжного издательства, 1985.

АЛ - Алтай литература. 5-6 класстарга. - Горно-Алтайск: Горно-Алтайское отделение Алтайского книжного издательства 1981.

ИС, ТУКА - И. Сабашкин. Турна ӱни кӧндӱгер алдында. - Горно-Алтайск: Горно-Алтайское отделение Алтайского книжного издательства, 1984.

ИШ, КЈ - И. Шодоев. Кызаланду јылдар. - Горно-Алтайск: Горно-Алтайское отделение Алтайского книжного издательства, 1972.

ЛК, А - Л. Кокышев. Арина. - Горно-Алтайск: Горно-Алтайское отделение Алтайского книжного издательства, 1959.

НУ, ЭС - Н. Улагашев. Эр-Самыр. - Горно-Алтайск: Горно-Алтайское отделение Алтайского книжного издательства, 1986.

НЯ, ЧК - Н. Ялатов. Чымалы-Каан. - Горно-Алтайск: Горно-Алтайское отделение Алтайского книжного издательства, 1988.

СС, Э - С. Сартакова. Эрјине. - Горно-Алтайск: Горно-Алтайская типография, 1995.

ТШ, ЫЭИ - Т. Шинжин. Ырыс экелген ижемји. - Горно-Алтайск: Горно-Алтайское отделение Алтайского книжного издательства, 1986.

ЭП, А - Э. Палкин. Алан. - Горно-Алтайск: Горно-Алтайское отделение Алтайского книжного издательства, 1978.

ЭТ, К - Э. Тоюшев. Кӱрлер. - Горно-Алтайск: Горно-Алтайское отделение Алтайского книжного издательства, 1987.

\section{References}

Altajsko-russkij slovar', 2018 - Altajsko-russkij slovar'. - Gorno-Altajsk, 2018. 936 s. [Altai-Russian dictionary. - Gorno-Altaysk, 2018. - 936 s.] [In Rus. and Altay]

Bajzhanova, 2002 - Bajzhanova N. R. Obrazovanie parnyh slov v altajskom yazyke // Tret'ya zimnyaya tipologicheskaya shkola: Mezhdunarodnaya shkola po lingvisticheskoj tipologii i antropologii. Moskovskaya oblast', 29 yanvarya - 6 fevralya 2002. Materialy lekcij i seminarov. M.: RGGU, 2002. - S.101-103. [Education paired words in Altai language//third winter typological school: an international school on linguistic typology and anthropology. Moskovskaya oblast, 6 January 29 February, 2002. Materials of lectures and seminars. Moscow: RSUH PUBL., 2002. - S.101103]. [In Rus.]

Belyakova, 2006 - Belyakova A. V. O parnyh slovah, obrazovannyh iz sinonimov // Filologicheskie issledovaniya (k 100-letiyu T. M. Toshakovoj). Gorno-Altajsk, 2006. - S. 52-57. [The paired words formed from synonyms // Philological research (to the 100 anniversaries of T.M. Toshakova). Gorno-Altaysk, 2006. - S.52-57]. [In Rus.]

Ganiev, 1982 - Ganiev F. A. Obrazovanie slozhnyh slov v tatarskom yazyke. - M.: Nauka. 1982. - 150 s. [The formation of compound words in the Tatar language. M.: "Nauka". 1982. - $150 \mathrm{~s}$.]. [In Rus.]

Garipov, 1959 - Garipov T. M. Bashkirskoe imennoe slovoobrazovanie. Ufa: BF AN SSR, 1959. 221 s. [Bashkir nominal morphology. UFA: Foundation for an SSR, 1959. - 221 s.]. [In Russ.]

Grammatika, 2005 - Grammatika altajskogo yazyka. Reprintnoe vosproizvedenie izdaniya «Grammatika altajskogo yazyka», (Kazan', 1869). - Gorno-Altajsk: izdatel'stvo "Ak Chechek», 2005. [Grammar of the Altai language. Reprint Edition of playback "Grammar of the Altai language" (Kazan, 1869). Gorno-Altaysk: Ak Chechek, 2005.]. [In Rus.]

Grammatika, 2017 - Grammatika sovremennogo altajskogo yazyka. Morphology. - Gorno-Altajsk, 2017. - 576 s. [Grammar of the modern language of Altai. Morphology. Gorno-Altaysk, 2017. 576 s.]. [In Rus.]

Dmitriev, 1948 - Dmitriev N.K. Grammatika bashkirskogo yazyka. M.; L.: Izd-vo AN SSSR, 1948. 607 s. [Grammar of the Bashkir language. M.; L, 1948. - 607 s.] [In Rus.]

Dyrenkova, 1940 - Dyrenkova N. P. Grammatika ojrotskogo yazyka - M.; L., 1940. - 304 s. [Grammar ojrotskogo language. M.; L, 1940. - 304 s.] [In Rus.]

Dyrheeva, Haranutova, Bardamova, 2014 - Dyrheeva G.A., Haranutova D. SH., Bardamova E.A. Parnye slova i parnoe slovoobrazovanie v buryatskom yazyke. Ulan-Ude, 2014. - 208 s. [Paired words and word pairs in the Buryat language. Ulan-Ude, 2014. - 208 s.] [In Rus.]

Kajdarov, 1958 - Kajdarov A. Parnye slova v sovremennom ujgurskom yazyke. Alma-Ata, 1958. 168 s. [Paired words in modern Uygur language. Alma-Ata, 1958. - 168 s.].[[In Rus.]

Kogunbaeva, 1991 - Kogunbaeva N. I. Altajsko-russkij slovar'. - Gorno-Altajsk, 1991. [Altai-Russian dictionary. Gorno-Altaysk, 1991]. [In Rus.] 
Kononov, 1960 - Kononov A. N. Grammatika sovremennogo uzbekskogo literaturnogo yazyka. M.; L., 1960. - 446 s. [A grammar of modern Uzbek literary language. M.; L., 1960. - 446 s.]. [In Rus.]

Mel'chuk, 1998 - Mel'chuk I. A. Kurs obshchej morfologii. II. M.: Vena, 1998. [Course of General morphology. II.-m.: Vienna, 1998]. [In Rus.]

Morfemnyj slovar' altajskogo yazyka, 2005 - Morfemnyj slovar' altajskogo yazykaю GornoAltajsk, 2005. [Morphological dictionary of the Altai language. Gorno-Altaysk, 2005. - 319 s. [In Rus and Altay]

Mujtueva, 2012 - Mujtueva I. N. Parnye slova v altajskom yazyke // YAzyki i literatura narodov Gornogo Altaya. Gorno-Altajsk: RIO GAGU, 2012. - S.152-154. [Paired words in Altai language// languages and literature of the peoples of the Altai Mountains. Gorno-Altaysk: RIO GAGU, 2012. - S.152-154]. [In Rus.]

Muratov, 1961 - Muratov S. N. Ustojchivye slovosochetaniya v tyurkskih yazykah. - M.: Vostochnaya literatura, 1961. - 131s. [Set-expressions in Turkic languages. M.: Eastern literature, 1961. 131s.]. [In Rus.]

Nadelyaev, 1988 - Nadelyaev V.M. Sovremennyj mongol'skij yazyk. Morfologiya. - Novosibirsk: Nauka, 1988. - 113s. [Modern Mongolian language. Morphology. Novosibirsk: Nauka, 1988. 113s.]. [In Rus.]

Ojrotsko-russkij slovar', 1947 - Ojrotsko-russkij slovar'. M.: OGIZ, 1947. [Ojrotsko-Russian. M.: OGIZ. 1947]. [In Rus. and Altay]

Ondar, 2004 - Ondar N. M. Somaticheskie parnye slova v tuvinskom yazyke // Aktual'nye problemy sohraneniya i razvitiya yazykov, kul'tur i istorii narodov Sayano-Altaya: Materialy mezhdunar. nauch. konf., posvyashchennoj 280-letiyu otkrytiya drevnetyurkskoj pis'mennosti. 20-23 sentyabrya $2001 \mathrm{~g}$. Abakan, 2001. - S.108-112. [Somatic paired words in Tuva language // Actual problems of preservation and development of the languages, cultures and history of the peoples of the Sayan-Altai: proceedings Internat. researcher. conf on 280-anniversary of opening of ancient Turkic writing. 20-23 September 2001 Abakan, 2001. - S.108-112]. [In Rus.]

Plungyan, 2000 - Plungyan V. A. Obshchaya morfologiya. Vvedenie v problematiku. M, 2000. [General morphology. Introduction to perspective. M, 2000] [In Rus.]

Semenova, 2005 - Semenova G. N. Kompozitoobrazovanie v chuvashskom yazyke i ego nacional'naya specifika. - M, 2005. - 318s. [Kompozitoobrazovanie in the Chuvash language and its national specifics. M, 2005. - 318s.]. [In Rus.]

Tarakanova, 2008 - Tarakanova I. M. Slovoobrazovanie imen sushchestvitel'nyh $v$ hakasskom yazyke (v sopostavitel'nom aspekte). - Abakan, 2008. - 174 s. [Word formation of nouns in sk, 2003. S.71-79]. [In Rus.]

Ubryatova, 1948 - Ubryatova E.I. the language concerns to (comparative aspect). Abakan, 2008. 174s.]. [In Rus.]

Tydykova, 2003 - Tydykova N. N. Lingvisticheskaya harakteristika lichnyh imyon v geroicheskom epose // Issledovaniya po altajskomu yazyku. - Gorno-Altajsk, 2003. - S.71-79. [Linguistic characteristics of personal names in the heroic epos // Studies on the administration of the language. Gorno-Altay

Parnye slova v yakutskom yazyke // YAzyk i myshlenie. - M.; L, 1948. № II. - S. 297-328. [Paired words in the Yakut language // Language and thinking. M.; L., 1948. № II. - S.297-328]. [In Rus.]

Chaychina, 2015 - Chaychina E.V. Bezaffiksal'noe slovoobrazovanie imen sushchestvitel'nyh // Grammatika sovremennogo altajskogo yazyka. Morfologiya. - Gorno-Altajsk, 2017. s.69-75. [Bezaffiksalnoe derivation of nouns//grammar of the modern language of Altai. Morphology. Gorno-Altaysk, 2017. - S. 69-75]. [In Rus.]

\section{Tekstovye istochniki i informant}

AA, OCHK - A. Adarov. Ölÿmniн charkyr kuzhy. - Gorno-Altajsk: knizhnoe izdatel'stvo «YUchSyumer», 1993.

AA, TJ - A. Adarov. Tÿndegi jyldystar. - Gorno-Altajsk: Gorno-Altajskoe otdelenie Altajskogo knizhnogo izdatel'stva, 1961.

AA, UBT - A. Adarov. Ucha bergen turnalar. - Gorno-Altajsk: Gorno-Altajskoe otdelenie Altajskogo knizhnogo izdatel'stva, 1980.

AB - Altaj baatyrlar. I-XII t.t. - Gorno-Altajsk: Gorno-Altajskoe otdelenie Altajskogo knizhnogo izdatel'stva, 1959-1995.

AJ - Altaj јан / Sost.: V. A. Mujtueva, M. P. CHochkina. - Gorno-Altajsk: Gorno-Altajskaya tipografiya, 1996.

AE, KJ -A. Eredeev. Kuulgazyndu jaj. - Gorno-Altajsk: Gorno-Altajskoe otdelenie Altajskogo knizhnogo izdatel'stva, 1985.

AL - Altaj literatura. 5-6 klasstarga. - Gorno-Altajsk: Gorno-Altajskoe otdelenie Altajskogo knizhnogo izdatel'stva 1981. 
IS, TŸKA - I. Sabashkin. Turna ÿni köndÿger aldynda. - Gorno-Altajsk: Gorno-Altajskoe otdelenie Altajskogo knizhnogo izdatel'stva, 1984.

ISH, KJ - I. Shodoev. Kyzalardu jyldar. - Gorno-Altajsk: Gorno-Altajskoe otdelenie Altajskogo knizhnogo izdatel'stva, 1972.

LK, A - L. Kokyshev. Arina. -Gorno-Altajsk: Gorno-Altajskoe otdelenie Altajskogo knizhnogo izdatel'stva, 1959.

NU, ES - N. Ulagashev. Er-Samyr. - Gorno-Altajsk: Gorno-Altajskoe otdelenie Altajskogo knizhnogo izdatel'stva, 1986

NYA, CHK - N. Yalatov. CHymaly-Kaan. - Gorno-Altajsk: Gorno-Altajskoe otdelenie Altajskogo knizhnogo izdatel'stva, 1988.

SS, E - S. Sartakova. Erjine. - Gorno-Altajsk: Gorno-Altajskaya tipografiya, 1995.

TSH, YEI - T. Shinzhin. Yrys ekelgen izhemji. - Gorno-Altajsk: Gorno-Altajskoe otdelenie Altajskogo knizhnogo izdatel'stva, 1986.

ET, K - E. Toyushev. Kÿrler. - Gorno-Altajsk: Gorno-Altajskoe otdelenie Altajskogo knizhnogo izdatel'stva, 1987. 